\title{
ENTRE PROUST Y LA MOMIA AMERICANA: Siete Notas y un Epílogo sobre El Recurso del Método.
}

"hemos llamado a todas las puertas que no llevan a ninguna parte, y la única practicable y que hemos buscado en vano durante cien años, se abre ante nosotros al tropezar casualmente con ella..." Marcel Proust, $A$ la recherche du temps perdu.

ARIEL DORFMAN

Por

Universidad de Amsterdam

Un incidente en El recurso del método ${ }^{1}$, la novela de Alejo Carpentier, ilustra y concentra toda la problemática de la obra: es el momeno en que el dictador, guareciéndose de una lluvia torrencial que adviene después de una victoria militar contra un general sublevado, se topa con siete momias en una cueva, entre las cuales hay una que le llama especialmente la atención por ser a todas luces el jefe, sacerdote, máximo guerrero, es decir, alguien que alguna vez, hace milenios, también fue Primer Magistrado en esta misma geografía

Quien fuera una rey americano es hoy muerte pura, deshechos embalsamados. No se conoce ni su nombre. Su cultura y civilización (sic) va a tomar el nombre de Río Verde, con lo que ni siquiera entregará a los siglos posteriores la denominación que él mismo se dio y balbució. Su destino final es viajar a Europa para ser colocado en una vitrina en el Museo del Trocadero. Peor aún, cuando la prensa francesa denuncie las matanzas de Nueva Córdoba, el Primer Magistrado intentará tapar el escándalo (que le impide el acceso a los salones parisinos) con una campaña de publicidad basada en ese "abuelo de América": el líder de un pueblo antiguo será manipulado para desviar la atención sobre las masacres actuales, para prestigiar a un gobierno más corrupto que sus residuos podridos. La reliquia será movida entre Gotemburgo y otros puertos oscuros, esperando que termine la primera guerra mundial para hallar el reposo, hélàs irónico, del museo. Ha sido reducido a su dimensión meramente pasiva y enajenada, polvo sin enamoramiento. Esta

1. Alejo Carpentier, El recurso del método (México, Siglo XXI, 1974). Todas las citas son de esta edición. 
condición de extrema impotencia de la momia queda subrayada por su yuxtaposición, en el mismo subcapítulo, con otro estadista dcsaparecido hace siglos, otro guerrero que, al contrario del monarca americano, está lejos de encontrarse marginado de la historia universal: se trata de Julio César. En efecto, el Primer Magistrado les explica a sus dos acólitos (el secretario Peralta y el Coronel Hoffmann) que la batalla que acaba de ganar se debió a haber empleado, paso a paso, la táctica sugerida por el general romano en sus Comentarios. Las lecturas del Primer Magistrado le han permitido aplicar lecciones escritas hace más de dos mil años, quizás en la misma época en que el hombre que ahora es calavera en una cueva putrefacta rigió su tribu o nación.

El contraste, por ende, no podría ser más desgarrador. Julio César ha logrado subsistir, imponerse más allá de su propia extinción física. Su influencia es tan vigorosa que hasta las batallas americanas se determinan de acuerdo a sus recomendaciones y memorias (sea porque el Primer Magistrado utiliza esa estrategia, sea porque la historia europea domina a tal grado la americana que la imita y presiona a repetir pálidamente sus ciclos, anécdotas y vaivenes). César fue dictador, centro del imperio, dueño del universo. Su "cultura" es el semillero del idioma mismo que habla el Primer Magistrado, en que se transmiten entre los expertos las características de ese otro rey, quizás coetáneo del romano. En una palabra, la momia y Julio César son dos caras de la misma medalla (militar), dos derroteros posibles de ultratumba para un gobernador, dos vías, alter ellos, de regir para permanecer. Ambos contemplados a milenios de distancia por otro soberano, otro hombre que también ha compuesto su biografía en función del poder, apostando a la capacidad de perdurar: el Primer Magistrado. Aquí está la esencia de la novela: el presidente perpetuo de Carpentier cree ser, quiere ser, como Julio César, y terminará siendo, ya lo es, como la momia. En realidad, está muerto y estancado cuando se abre la narración, ya es estatua irreconocible y carcomida debajo del mar, caudillo derruído para siempre por la desmemoria. Periferia pura, entera marginalidad, olvido absoluto. Será como la momia: exhibido en el museo de los Dictadores Repetidos que Alejo Carpentier establece en su caverna (anti-platónica) del lenguaje.

Más que una denuncia en contra de tiranías que hemos padecido y que aborrecemos, El recurso del Método es la lenta, sarcástica exploración del ejercicio del poder, bastardo, secundario, ilusivo, en un continente subdesarrollado. El Primer Magistrado buscará persistir, sólo dándose cuenta-y eso a medias-de que el poder nunca fue verdaderamente suyo, sino que dependía de los reales propietarios del mundo: los Julio y César de ahora, los amos del imperium-empire del siglo XX, el norteamericano. 
El modo en que el Primer Magistrado concibe y desarrolla su autoridad lo conduce irremisiblemente a la ignominia de la momia, a servir, en el mejor de los casos, de ilustración para escolares europeos, asterisco sin lámina al pie de una página anexa. Por eso no se trata de un panfleto que nos entrega aquello que ya sabemos de sobra (por los periódicos o por los cuerpos), por eso no es un monigote: conviviremos con el deseo del Primer Magistrado de sobrevivir a su tiempo, en alguna parte: seremos su ceguera de que lo está alcanzando, de que voluntad e historia marchan al unísono. Pero debido a que se suma a esa historia como opresión, como tuerca del aparato dominador, debido a que delata a cada momento la perspectiva liberadora, está condenado a ser fósil, a ser nada, a ser reflejo en una vitrina.

Años despues de la batalla (romana) de Río Verde, trece años después para ser exactos, el Primer Magistrado, ya derrocado, ya sin país ni comando, irá a visitar a la momia. Será su último acto antes de morir, casi como un obsceno rito voyeurista de tránsito hacia la agonía.

"No te quejes, cabrón, que te saqué de tu fanguero para hacerte gente... Para hacerte gen-" (p.334). Hacerte gente. Así le habla el ex-dictador al montón de huesos unos días antes de que él mismo se transforme también en materia inanimada. Se auto-erige en divinidad que extrae a ciertos seres inferiores del lodo y los coloca en otro sitial, entre la "gente", perseverando hacia el futuro por medio de colecciones y Trocaderos europeos. Esta operación transmutativa (de la tierra sin forma a la supremacía de ser "gente") contiene y representa el proyecto vital del Primer Magistrado. Y no se trata tan sólo del núcleo de sus propias quimeras, sino hacia dónde quisiera empujar el país mismo.

Pero ien qué consiste "hacerse (me) (te) gente"?

Dos ejemplos lo pueden dilucidar.

Primero: cuando se rebela el general Ataúlfo Galván, una de las lamentaciones más amargas del Primer Magistrado se impregna de las siguientes palabras: a ese militar se lo "sacó de la mugre de un cuartel de provincia... haciéndolo gente." (p. 31).

Segundo: cuando arriba la ópera al "inculto" país americano, el protagonista observa que sus conciudadanos comienzan a adoptar las costumbres y horarios del Viejo Mundo: "Nos estamos haciendo gente, Peralta; nos estamos haciend่o gente." (p. 199). La momia, el general, los asistentes a la ópera: todos siguen la misma trayectoria, desde la ignorancia 
sucia y atrasada, hasta la luminosidad pulcra del poder y de la civilización. Toda la política del Primer Magistrado va a consistir en adorar este binomio que confiere la perdurabilidad: el poder americano y la cultura europea. Hasta podría aventurarse: el poder americano para poseer la cultura europea.

Hacerse gente. Era la ilusión de un periodista miserable perdido en un puerto del Pacífico, llamado significativamente Surgidero: ser aceptado como un igual en los salones europeos, departir con los patrones de la palabra y los dispensadores de los fulgores civilizados. Para eso, alzarse con el gobierno y ganarse el derecho a esos umbrales. Para eso, tener que volver de tiempo en tiempo a sofocar las rebeliones de militares díscolos, profesores iracundos y pueblos desobedientes. Para eso, seguir soñando con el retorno a Europa, una vejez tranquila entre pinturas, música, literatura $\mathrm{y}-\mathrm{lo}$ que es más importante-chismes de alta alcurnia, "alguien", en los ojos de quienes poseen el derecho de la habladuría, "alguien", por fin, gente. De manera que el designio del Primer Magistrado será el de todo colonizado: dejar atrás la tierra original para incorporarse a los valores "superiores", ser miembro conspicuo de aquel sector de la humanidad propietario de los cañones, las fábricas y los fonemas, "garantores" de un lugarcito en los diccionarios, los manuales de historia y los placeres y alegrías de la actualidad.

Lo interesante no es el proyecto, cuya versión menos sofisticada soportamos en la televisión, el cine y los comics de cada día, sino que está en las razones de su fracaso, en la implacable mirada crítica con que el novelista logra desnudarlo, en la exhumación de aquellas fuerzas que marchan en un sentido inverso y que resisten esa empresa mimetizadora. Así, el hecho de que la novela desarrolla su acción en un vaivén entre dos escenarios principales (la enclaustrada residencia parisina y la simbólica vastedad plural del territorio americano inventado), no es más que un correlato de un incesante pasaje de idea y de vuelta entre Europa y América en la vacilante conciencia del pícaro convertido en tirano. ${ }^{2}$ Antes que el intento de un americano de transformarse en europeo, presenciamos la imposibilidad de aquella tentativa. El movimiento pendular que aqueja y sacude a quién ha emplazado la brújula de su vida en esa dirección dominante, concluye siendo un ejercicio en el descubrimiento (para el lector, al menos) de lo que es irreductible y genuinamente americano. Ambos polos se inter-revelan y comentan a partir de la empresa que tiende a negar a uno de ellos, haciéndonos recobrar aquello que le es propio a

2. Es Carpentier mismo el que ha llamado la atención sobre esta característica de su política: "... en mi novela quise hacer la picaresca del dictador", un pícaro que se había agigantado en un continente gigante. (En entrevista con Miguel F. Roa, "Alejo Carpentier: el recurso a Descartes, en Granma, 18 de mayo de 1974). 
cada dimensión. Más allá del incierto terreno en que se comparten influencias, en que se imita y se encubre, en que se erigen espejos, más allá de los mitos y las máscaras, irán apareciendo - aún para el dominado por antonomasia, para el dictador "culto"-_ciertas duras, flexibles, irredentas características. Porque mientras el Primer Magistrado presume avanzar hacia el porvenir de la cultura europea, su verdadero viaje es a la tierra, tierra de la muerte que será suya, tierra de la vida que no podrá sembrar, el hacia atrás de la tierra que quiso traicionar y que termina siendo lo único real y valedero en medio de las falsificaciones y los espejismos. Instalados en la óptica del dominado que quiso ser dominante, del él que aspira a pronunciar la pobre partícula yo, estamos sometidos a una doble lectura, abarcando simultáneamente la distancia de lo europeo y la cercanía de la resistencia que opone la realidad al sueño de cenicienta (docto y sanguinario) del anti-héroe. Distancia y poderío de lo europeo incapaz de acallar lo americano; cercanía y pasividad de lo americano capaz de fracturar los deseos de olvido y exterminio. Acá y allá, allá y acá, sin salirnos de la conciencia de alguien que se anida en la ineludible intersección de esos mundos, llevamos a cabo un diálogo entre Europa y América en la región del conocimiento y de la estética (por medio de la narración), y establecemos que la base auténtica para ese diálogo en la historia sólo podrá llevarse a cabo a condición de que los habitantes de nuestro continente extiendan sus existencias en el sendero contrapuesto al del Primer Magistrado, pongan en acción la perspectiva liberadora con que el narrador vislumbra, desmantela y hace crisis los equívocos e impracticables preceptos del gobernante colonizado. En todo caso, la ironía con que se construye y demuele la vida y hechos del rufián ilustrado ya es una prueba y anticipación de que existe una alternativa frente a su proyecto.

\section{III}

Desde el inicio llama la atención la extraordinaria fragilidad de los designios del Primer Magistrado, su inconsistencia, diríamos, casi estructural. Su eventual desembarco en las "altas" comunidades intelectuales y sociales de Europa descansa en su aptitud para renovar, de cuando en cuando, las fuentes levantiscas y esquivas de su poder americano. En este sentido, repite el incesante regreso con que sueñan todos los segundones y marginales que partieron a las Indias como conquistadores, emigrando para hacer fortuna e impresionar (imponer su presencia) al Viejo Mundo, y descubre, como ellos, que ya está ligado a las nuevas comarcas por vínculos que tornan imposible la reintegración al continente paterno. 
En el caso del Primer Magistrado, la llave a los ventanales deslumbrantes reside en su talento para ser rico y poderoso y ese poder debe ejercerse con una virulencia tajante. En términos de la novela: para disfrutar del discurso del método, hay que utilizar el recurso del método. $O$ de otro modo, más tosco y rudo: para acceder a los salones de acá, se debe robar, matar, mentir allá. Lo que no es sino la re-edición de la peripecia de conquista, saqueo y expoliación, sin los cuales no habría Europa como hoy la contemplamos. Pero nuestro héroe, como neo-colonial recalcitrante, ha llegado con atraso: lo que los europeos hicieron con sus colonias durante siglos, no es aceptable para la civilización y las normas del savoir-faire (del savoir-taire) de ahora. La paradoja es evidente: sin ese poder, él no es nadie. Pero con ese poder, cuyas reglas no han variado, él es tratado como nadie.

Esta encrucijada se le revela dos veces en la novela,en dos episodios que aparecen calcados el uno del otro. En ambas ocasiones, está ejecutando su ritual cotidiano en su mansión de la rue Tilsit, dedicado a recoger los frutos y las flores de su posición de hombre educado, dilapidando un conocimiento de la cultura occidental mucho mayor que el de cualquier europeo sano y normal ${ }^{3}$, cuando recibe las noticias de un alzamiento miltiar en su propio país. Cambia de inmediato su perspectiva vital $y$, correlativamente, el ritmo narrativo. Hasta hay un paso, dramático en un caso, imperceptible en el segundo, desde el yo al él, desde su figura eje hasta su figura impotente y tangencial. Debe dejar Europa y volver a recuperar lo suyo, debe ejercitar la reciedumbre y el instinto que lo malguiaron hasta su coyuntura actual, debe ser más macho, implacable y astuto que los demás. Recordando las palabras de un actor que hacía de Cristo en una festividad popular y al cual trataron de ayudarle a cargar la cruz, nuestro Anti-Cristo le dice a su secretario: "Y si me quitara aquello, ¿que sería yo, qué me quedaría?" (p. 131).

He aquí una primera muestra de la endeblez de su proyecto. Tiene, en muchos sentidos, los pies de barro. Su provinciano pasaporte hacia la cultura pasa por la barbarie 4 . No nació legitimado ante ese lugar que es "el único sitio del Universo donde la opinión ajena tuviese aún, para él, algún valor." (pp. 101-102). El derecho a ser europeo está constantemente puesto a prueba, como el de todo recién llegado. No ha habido tiempo para borrar o mitificar las fuentes de su riqueza, para ideologizar su acumulación de poder y engaño: en las colonias, decía Marx, se ve con toda su desnudez la

3. Esta característica acerca a nuestro pícaro ilustrado a ... Jorge Luis Borges, en la interpretación de Roberto Fernández Retamar (Calibán y otros ensayos, La Habana: Cuadernos de Arte y Sociedad, Editorial Arte y Literatura, 1979, véanse pp. 57-63)

4. Graziella Pogolotti ha llevado a cabo un fino análisis acerca del "falso asidero cultural" del anti-héroe y el desarraigo y violencia resultantes. (En "Carpentier renovado", Casa de las Américas, Septiembre-Octubre 1974, Año XV, N. 86, pp. 127-129) 
fuerza brutalizadora del capitalismo. El Primer Magistrado debe materializar en el largo y fugaz relampagazo de su vida lo que las potencias hegemónicas tardaron siglos en fundar. Está atrapado en una puerta giratoria: apenas entra, ya está saliendo. $Y$ para nada valen sus amargas quejas ante tamaña hipocresía o las denuncias de Peralta acerca de la salvaje historia europea. Poco importan las hecatombes, plagas y persecuciones (no pocas ejercidas contra los antepasados tricontinentales de nuestro Primer Magistrado), poco importa que la primera guerrra mundial (y dentro de poco, la segunda) supere con creces las vesanías del asesinato masivo. El dictadorzuelo rezagado quedará excluido y desterrado (sic) de los salones: es intolerable para los euorpeos esta imagen de sí mismos, esta deformidad que ellos han creado, que ellos han sido, que ellos siguen y seguirán siendo. Sin esa violencia, no hay modo de "subir" en el mundo y recibir el homenaje y la atención de los dominadores, los que abren las puertas del porvenir. Pero con esa violencia, él se aleja a la vez de esa "gente" que no desea admitir sus propios orígenes ni tampoco es capaz de atisbar su propia crisis que se avecina en el horizonte de esos años. Se trata de una clase social que, en las palabras de Walter Benjamin, "jura en todas partes hacer el camuflaje de su base material y que por esta misma razón se amarra a un feudalismo que no tiene significación económica intrínseca, pero que sirve como máscara para la clase medida alta." ${ }^{5} \mathrm{~A}$ los monstruos no les gusta el espejo. Lo que nos lleva a la segunda condición precaria. La cultura a la que aspira arribar el Primer Magistrado es, dentro de Europa misma, regresiva, conservadora, tradicional, mera apariencia. Es una cultura puesta al servicio de la vida social en las órbitas mundanas, signo exterior de un status, moneda de intercambio en el leisure class que analizó Thorstein Veblen con bastante rigor ${ }^{6}$. El arte es moda y modales, pero no modificación. Esto queda expuesto al final del libro cuando el exdictador arremete contra todo el arte moderno que su hija ha adoptado, aunque mucho antes ya se notaba su molestia frente a lo que será la gran aventura estética del siglo XX. Es una de las escenas más graciosas de la novela, y acaso la más patética. Él se está integrando a los gustos y a las usanzas de una época que ya está pereciendo, él ama un arte petrificado y neo-clásico que intenta postular un orden burgués eterno e inalterable, asfixiándose en reglas y nostalgias mezquinas, precisamente en el momento en que la vanguardia asalta y explora la crisis. Es víctima, según Mejía Duque, de un "anacronismo patriarcal." 7 Como todo colonizado,

5. Walter Benjamin, en el ensayo, "The Image of Proust" (En Illuminations, Fontana/Collins, London, 1977 (second impression), p. 212).

6. Thorstein Veblen, Theory of the Leisure Class.

7. Jaime Mejia Duque, "Los recursos de un novelista", (En Recopilación de textos sobre Alejo Carpentier, Serie Valoración Múltiple, Casa de las Américas, 1977, compilación y prólogo de Salvador Arias, p. 441). 
entonces, el Primer Magistrado quiere ser aceptado, a lo simio, por el orden establecido, y se opone tenazmente a las fuerzas de la renovación, disidencia y experimento. Lo que tendrá, incluso, consecuencias políticas: como veremos, el hecho de que sea un europeizado rumiante del siglo XIX lo coloca al margen de las readecuadaciones indispensables para conservar el poder en un siglo que será dominado crecientemente por los EE.UU. y su imperialismo más dinámico y tecnológico.

Así, su proyecto va en contra de las corrientes actuales de la historia, en cuanto nace en el anhelo de una Europa que ya está siendo sustituída por otro imperio. Pero más que eso, se arraiga en la confianza de que la cultura (el acto de fabular y conversar) lo puede salvar, enaltecer, otorgar prestigio, un mito que está siendo remordido y resquemado por las conciencias artísticas e intelectuales más avanzadas de ese mismo continente, para no hablar de sus fuerzas sociales y revolucionarias. El quiere cruzar por los salones en los años exactos en que se vuelven más vacíos, vacuos e insignificantes de lo que nunca lo fueron. Para variar, el colonizado viene a ser el último recinto sofocado donde se apagan los débiles ecos de ideales ya invalidados y sin envergadura en sus países generadores. La cultura, para él, no es un instrumento de mayor humanidad y contacto, sino advertencia pública de que él pertenece a los ritos civilizados, de que pertenece acá y no allá, un recurso como tantos otros, un método. Con obediencia de niño indefenso, aprende el código de una cultura que él no reconoce como gestos y residuos pasatistas ${ }^{8}$ frente a la emergencia de nuevos elementos.

Es interesante agregar que son dos los intelectuales (fuera de su sastre y su barbero) que le conservan, despues, de saberse lo de la masacre, cierta "fidelidad": el Ilustre Académico y D'Annunzio. Si bien ambos lo hacen para seguir profitando de su mecenazgo, importa situar esta alianza con más precisión. Los "cultos" que no lo descartan, son los ultra-derechistas, los adalides de un proto-facismo. Las recomendaciones de lectura del Ilustre Académico, incluyen, además de una serie de autores vetustos, a su amigo, Barrès y al racista Gobineau. Se comprende por qué no tiene asco de las andanzas y fechorías del dictador americano un íntimo de quiénes, precisamente en 1913, ya se agrupaban en torno a Sorel y Drieu La Rochelle, para fundar lo que sería L'Action Francaise. ${ }^{9}$

8. Utilizamos para este tipo de cultura la denominación que Raymond Williams le ha colocado (residual) en una elaboración de gérmenes contenidos en Gramsci. (Raymond Williams, Marxism and Literature, Oxford University Press, 1977, capítulo "Dominant, Residual and Emergent", pp. 121-127).

9. Se puede consultar el artículo de Zeev Sternhell, "Fascist Ideology", en Fascism, A Reader's guide (edited by Walter Laqueur, Penguin, 1979, pp. 325-406). Es de notar que el año 1972, cuando Carpentier trabajaba en El recurso del método, aparecieron dos libros sobre Barrès y el fascismo, que fueron reseñados en los periódicos de París y que nuestro autor debe haber leido. 
Pero esta tendencia conservadora es más honda en el personaje de lo que hasta ahora habíamos supuesto. Su intento retardatorio alcanza más allá de sus recursos políticos o de sus discursos retóricos: se trata del modo en que coordina su vida diaria, tratando de burlar el paso del tiempo, de especificar un fundamento de actos familiares, repetitivos y repetibles, que terminan inmovilizando en el cemento del hábito todo transcurso y azar. De manera que su aspiración al poder perenne y a una espiritualidad sublime e inmortal trasunta un deseo, en el fondo, más irrevocable: construir un mundo (o sea, un país, una conciencia, una terraza) en la que el tiempo (y por lo tanto la historia) no penetre. Con esto se une a las legiones de personajes de Carpentier inútilmente animados por la misma obsesión: detener el devenir, salirse de la historia, fugarse de la muerte pequeña de cada día para residir en algún círculo invariable. Aunque esta apetencia cíclica recorre todo el libro, su consignación más visible se establece en una serie de episodios, idénticos entre sí, en que el protagonista despierta, siempre a los mismos objetos, siempre respondiendo con los mismos vocablos, con una semejante arquitectura de gesticulaciones y actitudes, posturas que acaban por crear en torno a sí una escenografía que pudiera dar la ilusión de que se ha logrado derrotar el movimiento del reloj. Paradójicamente, su participación en los acontecimientos históricos se alimenta con la secreta porfía de abolirlos. Nadie podrá acusarnos de arruinar el suspenso de este ensayo si adelantamos que nuestro héroe no lo logrará.

Durante años, el Primer Magistrado llevará a cabo los ademanes del dictador prototípico: aplastar rebeliones, reprimir a la oposición, henchir el aire de palabras gastadas, edificar cárceles y bancos, manejar los hilos de los fraudes y de los cuarteles. En cada ocasión, él se presentará a sí mismo como el protagonista que ocupa la pista central del circo, estimará ser el sujeto activo y agente de la historia, el que obliga, con un minúsculo dedo de la voluntad, el rumbo que requieren las acciones. Esta noción de su poderío se verá reforzada por el modo narrativo que tiende a relatarnos lo que ocurre desde la perspectiva de su propia aprehensión.

A pesar de ello, deberá finalmente despertar ante el hecho de que la verdad es otra: es la historia la que lo modela y mueve a él, son otros seres humanos los que en efecto controlan su destino. Si bien existe un momento concreto en que esta situación suya, de pasividad e impotencia, queda evidenciada como una revelación que nunca lo ha de dejar, el momento en que es derrocado con el placet de sus otrora protectores yanquis, hay síntomas e indicios esparcidos a lo largo del libro de que él, más que la 
mano, es un instrumento que esa mano maneja. No se trata tan sólo de las múltiples ocasiones en que queda claro que sin el apoyo extranjero su gobierno se derrumbaría. Si fuera esto, y nada más, la función de esta obra no sería otra que la del panfleto, denunciando algo que, por archisufrido, no necesita validación literaria para ser comprobado: la fuerza militar, económica y política del imperio es lo que decide la suerte (y, claro está, la fortuna) de las oligarquías locales. Lo que hace Carpentier es mucho más importante, y menos obvio y exterior: desde la mente de un hombre que conjetura ser el director de sí mismo y de su país, en medio de la propia certeza de que es así, se despliega una contra-visión que desmiente y corroe esa certidumbre.

Porque la historia pasa, y ese paso se manifiesta en variaciones totales en todos los ámbitos y atmósferas de la vida: las costumbres, las canciones, la urbanización y arquitectura, los ciclos de exportación e importación, las lecturas infantiles, los coloquialismos, los modales, las fiestas populares, van absorbiendo radicales trastornos. Es lo que Carpentier ha llamado en otra parte un contexto (Tientos y diferencias) y que es la vivencia comunitaria de la totalidad socio-cultural-económica. Frente a este movimiento irreprimible, en que el país básicamente va padeciendo alteraciones venidas desde el exterior, el gran macho voluntarioso que es el presidente se considera impotente y triste ("contemplando aquella ubre que le crecía y le crecía, el Primer Magistrado se angustiaba a veces ante la modificación del paisaje visto desde las ventanas del Palacio...", p. 151). El no puede dejar de tranformarse en espectador, víctima de estos resquebrajamientos que ocurren fuera del radio de sus deseos. Ni tampoco logra sacudirse la sensación de que su país, y su biografía, se vuelven un mero espectáculo, drama, representación, fachada, ópera, carnaval, tragedia, escenario, baile de máscaras, núcleos de acción que ocupan, además, buena parte del argumento de la novela. Una y otra vez se nos presentan esos cambios en el contexto como manifestaciones de un gran tramo ya de la historia, donde se levantan edificios hoy para derribarlos mañana, donde se presta dinero inexistente, donde se vende y compra lo inútil, y todo el proceso económico y material se realiza sin que obedezca a ninguna razón profunda en el desarrollo de la nación misma. A esto se agrega el hecho de que el Primer Magistrado es, ante todo, un simulador, alguien que calcula su rostro y escaramuzas en virtud de la impresión que producirá en los demás, enajenación y fetichismo que ya señalamos como la base de la vida burguesa de la Bèlle epoque en Europa. Este juego de sombras e ilusiones, donde gana el que logra disfrazarse, aparentar, engañar a los demás y asímismo, convierte al mandatario en recadero y al país en una ruina (una ruina antes de ser monumento, una ruina en el instante mismo en que se construye). Nuevamente, determinadas 
actividades que él lleva a cabo surten un efecto contrario al que había planeado. Antes reparamos en el hecho de que, para constituirse en figura respetable de los salones, debía enajenar su propio país. Ahora vemos de qué manera conservar el poder significa entregar el conjunto de la nación (no sólo sus riquezas naturales, sino también sus riquezas culturales, su identidad social, su materialidad contextual y cotidiana) al febril ritmo que le impone la domesticación foránea. Con lo que barre todas las formas tradicionales que él ama en el fondo ( $\mathrm{y}$ a veces en la superficie) de sí mismo, lo que en su cuerpo y su íntima emoción siguen siendo una incitación hacia otra dirección posible. Queda pasmado, entonces, ante los cambios históricos, como si los estuviera viendo en una pantalla o arriba de un escenario, como si no fuera él mismo el responsable último de que esto suceda de esta manera y no de otra. Proclamar que ese sentimiento de nostalgia ante mutaciones que no ansía pero a las que ha contribuído con entusiasmo delirante sea una pura hipocresía o un gesto histriónico, pudiera darnos una amplia satisfacción moral pero ayuda poco a comprender el trasfondo del personaje: ese dolor es tanto el producto de la tendencia regresiva y conservadora como, por otra parte, de la intuición de que él también es víctima de lo que sucede, destructor de lo que más ama, un pícaro menor en la inmensa farsa universal. Lo que importa es notar que el contundente factum del imperialismo convierte a sus satélites (los humanos y las comarcas) en efímeros escenarios teatrales en que las parejas del Ballo in maschera no pueden depurarse de la convicción de que todo se dirige y controla desde otra parte, y que vamos fingiendo en feria y birlibirloque, y aquella orquesta lejana que toca la música nada tiene que ver con nuestros tendones y brazos y riñones y músculos.

Este caracter ilusorio, dramático, del país, esta visión de que todo es irreal y ficticio, incluyendo el poder ejecutivo, culmina justamente el día anterior al derrocamiento del Primer Magistrado, aunque ya se había plasmado en las reales maravillas de burlas que trastocaban la normalidad cotidiana ("Nadie creía ya en nada", pp. 228-230: la desarticulación del país por los opositores). Ante una huelga general que estalla, él extrema la condición bufa de la realidad con dos acciones: la primera es una batalla campal de sus soldados contra maniquíes; la segunda, la proclamación de su propia muerte para poder reprimir a los celebrantes. Tales recursos ya no lo pueden salvar: la crisis verdadera no soporta que prosiga la opereta. La ceguera del Primer Magistrado, que lo ha acompañado en medio de su violencia y de sus trucos, ha aterrizado en su punto final.

La próxima tarde, él despertará a la confusión, a la mutación y metamorfosis de formas, a "esas decoraciones cambiadas, de repente, por los tramoyistas de tragedias secretamente germinadas, crecidas en la sombra, nacidas en torno mío, sin que ensordecido por otros coros $\mathrm{X}$, 
hubiese oído el sonido de los coros verdaderos..." (p. 267). Disfrazado de enfermo ( $\mathrm{y}$ lo es), reducido a su máxima y ahora evidente impotencia, haciéndose el muerto aquél que había fingido la muerte el día anterior, deberá huir vergonzosamente, dándose cuenta por fin de quiénes son los verdaderos amos, "las Grandes Voces Cantantes." El gran teatro del mundo, la vida es sueño, el engaño es ilusión, la vida se nos presta, revelación del verdadero Dios (o rey) todopoderoso que componía detrás de la cortina: tema del barroco español que cobran, en este libro, un sentido social y tercer mundista obvio. El pícaro americano se percata de la auténtica estructura del mundo, de su situación objetiva en la jerarquía de la existencia y en la jerarquía del subdesarrrollo; si lo anterior fue un sueño o una obra teatral, es porque otros armaban la escenografía o escribían el libreto. El Primer Magistrado es tan vulnerable como el país que creía gobernar. Mucho más vulnerable, según hemos de ver. Sin el poder americano, no podía atracar en la sociedad y la cultura europeas. Pero sin el apoyo de su pueblo, sin fuerzas vitales y masivas propias para poner en la balanza, ese poder no aguanta ni se prolonga más allá de lo que son las conveniencias de los auténticos propietarios del emporio.

Antes, sin embargo, de examinar, por fin, este otro elemento (la lucha popular) que hasta ahora habíamos dejado a propósito de lado, vale la pena adentrarnos algo más en la concepción de la historia que se plantea en este libro.

La historia del país se nos manifiesta a través de dos expresiones simultáneas. Por una parte, estamos en presencia de un corte cronológico relativamente rígido. Vemos el país evolucionar desde 1913 hasta 1927, siguiendo con sincronización pasmosa (a pesar de algunas libertades) el acontecer efectivo en su ordenamiento real. Carpentier ha hecho entrar al libro todo su fabuloso-utilizamos el término con propiedad-acervo de lecturas y conocimientos de la cultura, recreando la época en cada detalle y observando en el micro y el macro, en lo minúsculo y lo mayúsculo, el vaivén de lo que fueron esos años. Pero, por otra parte, como ha sucedido tantas veces en otras obras suyas (el más reciente ejemplo es El arpa y la sombra, ${ }^{10}$ hay un sustrato más permanente en la historia, $\mathrm{y}$ el hecho que ocurre representa a la vez un incidente o una situación que, teniendo ubicación objetiva y verídica, de fuente comprobable, ocurrió ya antes y volverá a ocurrir otra vez en el futuro. Si la primera visión de la historia es

10. En esta novela, por ejemplo, la descripción del Chile post-independentista en el siglo XIX es una anunciación y superposición del Chile de Pinochet. Este procedimiento ya fue empleado en las primeras cien páginas de $\mathrm{El}$ siglo de las luces, que se presentan de manera que no sepamos si se trata del siglo XVIII o del siglo XX. 
cronológica, a la segunda la podemos llamar estructural 11 . En el transcurso del reinado del Primer Magistrado, históricamente circunscrito a catorce años, vemos masacres que se han repetido a lo largo de América, vamos condensando cohechos en el plebiscito, computando levantamientos que parecen calcados uno del otro: cuartelazos, fraudes electorales y financieros, incautación de libros, etc.

Ambas corrientes de la historia, lo que es único y se da una vez, y es situable con nombre, apellido, región geográfica, fecha; y lo que se da cíclicamente y apunta a la verdad subyacente, concurren para armar un país ficticio que está compuesto de todos los países latinoamericanos (si bien creemos reconocer una preponderancia de Venezuela) en todas sus épocas. Si Los pasos perdidos es la separación analítica de capas geológicas superpuestas que coexisten en un momento histórico mediante el expediente de un viaje por etapas, El recurso del método lleva a cabo la condensación sintética. El dictador mismo, el variado territorio del país, su historia, están armados a modo de un mosaico o de un vitral gótico ${ }^{12}$. Se trata, tal vez, del rasgo estilístico más destacado de la novela: manteniéndose dentro de límites fácticos bastante tajantes, se esboza un panorama que va más allá del período, del país o del tirano mismo. Pero sin caer en la alegoría o el símbolo, en una mera representación. Este viaje entre lo concreto y lo invisible, entre el arquetipo y la pequeñez cotidiana, ha sido estudiado ya muchas veces, y es la base del arte tan personal de Carpentier $\mathrm{y}$, podemos agregar de paso, una de las características sobresalientes de su generación.

Este excurso acerca de la historia se justifica, en nuestro caso, porque es la clave que abre y acompaña la vida del dictador. Él cree estar morando en la historia cronológica, haciéndola, montándosela, cuando de veras está sufriendo (y haciendo sufrir, lo que es peor) aquello que es permanente; matanzas, dependencia, robo, cuartelazos, retórica vacía. Él es alguien que la historia posee, y no al revés. Puede ser, durante un lapso, el beneficiario, el gozador, el que aprieta el gatillo, pero nunca llegará a ser el sujeto de la historia. Está condenado a vacilar entre las dos dimensiones de su país y de su ser: las verdaderas fuerzas son otras que la suya. Estamos ante la narración de un ejemplar único, irrepetible y existencial, y que es, a la vez, todo dictador latinoamericano.

11. Ya Noel Salomón había estudiado el tratamiento de la historia como dos tiempos superpuestos (en El siglo de las luces), conciliados entre sí por lo que él definió, con mucha propiedad, como una "estética de la imprecisión." (En "El siglo de las luces: historia e imaginación", Recopilación, pp. 395-428).

12. Esta idea de los vitrales se la debemos al mismo Carpentier, que describe bajo esa forma la percepción ocasional del Primer Magistrado (pp. 182-183). 
Esta circularidad precaria, aparatosa y satánica de su existencia, en la que no cabe evolución, progreso o cambio genuino, se le patentiza en un momento dado, al tener que retornar a combatir a Hoffmann, que se ha alzado:

"La historia era la suya puesto que en ella desempeñaba un papel, era historia que se repetía, se mordía la cola, se tragaba a sí misma, se inmovilizaba cada vez-poco importaba que las hojas de los calendarios ostentaran un 185(?), 189(?), 190(?), 190(¿6?)... - -era un mismo desfile de uniformes y levitas, de altas chisteras a la inglesa alternando con cascos emplumados a la boliviana, como ocurre en los teatros de poca figuración donde se hacen cortejos triunfales con treinta hombres que pasan y vuelven a pasar frente al mismo telón, corriendo, cuando están detrás de él, para volver a entrar a tiempo en el escenario gritando, por quinta vez: ¡Victoria! ¡Viva el Orden! ¡Viva el Orden! ¡Viva la Libertad! ... Tiempo detenido en un cuartelazo, toque de queda, suspensión de garantías constitucionales, restablecimiento de la normalidad, y palabras, palabras, palabras. . . que son, cada vez, como el regreso de un reloj a su posición de ayer cuando ayer marchaban las horas de hoy ..." (128-129)

Todos sus esfuerzos, entonces, lo conducen hacia la extrema inercia a la que despierta el día de su derrocamiento, simbolizado al final de la jornada por la visión del pueblo echando sus estatuas al mar. El Agente Consular norteamericano evoca el destino de esas obras que él edificó para su propia glorificación. Serán recogidas en miles de años más, pasando lo mismo que con "las esculturas romanas de mala época que pueden verse en muchos museos", perdiéndose los nombres propios y quedando sólo la denominación arquetípica, genérica: "Busto, estatua, de Un Dictador. Fueron tantos y serán tantos todavía, en este hemisferio, que el nombre será lo de menos." (p. 293)

La organización de la historia en ciclos de candilejas, su plasmación teatral y farsesca, la petrificación en modelos reiterativos y sin originalidad, todos estos rasgos que, por lo demás, han surgido y una y otra vez en la literatura hispanoamericana de este siglo como panorama esencial de nuestra representación sensible, están exhibidas acá como el producto del ser periférico y dependiente de nuestro continente. No se trata, en consecuencia, de una tendencia metafísica, sino del hecho de que estos dictadores y muchos de sus súbditos padecen la enajenación de su vida, un extravío efectivo de la identidad que los hace sentir (y expresar) la realidad de esa manera rutinaria.

Nuevamente vale la pena recurrir al ejemplo romano, y más aún en las presentes circunstancias. No sólo en torno al incidente de la momia, sino que en cada recoveco de la obra se nos ha recordado el paralelismo con aquel gran imperio de la antigüedad. El Primer Magistrado gusta de perorar en latín, buscando frases clichés memorables para cada ocasión. 
Incluso su último aliento se dispendia en tres vocablos romanos ("Acta est fabula"), que, por cierto, nadie entiende. Cuando enfrenta al Estudiante, su mayor adversario, y el que encabezará el movimiento de masas que fuerce a los norteamericanos a buscarle un reemplazante, le explica la cruda realidad de que "los gringos son los romanos de América. Y contra Roma no se puede." (p. 240). Por lo que no nos sorprendemos cuando, unas páginas más tarde, al preguntarle si acaso él no lo ve como Calígula, recibe la cruel e irreverente respuesta de que más bien se parece al Caballo que al Emperador Romano. Son esas insolencias las que recuerda al contemplar sus esculturas despedazadas por el pueblo, cortando su latín del instante: "Memento homi...", frase que nunca redondea. Es intersante notar, de paso, que lo que se destroza en las estatuas no es únicamente la estampa del dictador, sino también el arte mismo neo-clásico, de pésimo gusto y peor factura, al que los gobiernos autoritarios tienden, desde Bonaparte hasta Mussolini, pasando por el de Guzmán Blanco. Lo que ha hecho con las estatuas es lo que ha hecho con su país: tomar la tierra y tratar de imponerle su efigie y su apellido, moldear el barro y la piedra hasta que se endurezca a su imagen y semejanza. Una que otra, como la momia, terminará en algún museo del futuro para ilustrar lo único persistente: existieron en aquella (en esta) triste época tiranos sordos, soberbios y fosilizados, cuyos nombres han caído en el olvido, y cuyas actividades de rompe-corazones eran hasta tal punto idénticas que resultan, a la postre, intercambiables como las piezas de un puzzle.

Años antes había llegado hasta ese mismo puerto atlántico en que él contempla ahora su propia devastación, otra estatua mandada a hacer en el extranjero, y que representaba la República. Esa gigantesca imagen (también greco-romana, de "Juno vaticana") tuvo que ser transportada hasta la capital en pedazos: su fragmentación era una elocuente manera de comentar la de la nación que decía representar y el sino final del hombre que la solicitó para el centenario de una "independencia" ficticia.

Si éstas fueran las únicas esculturas en el libro, podriámos pensar que Carpentier se ha quedado él mismo fascinado en los callejones aparentemente sin salida del ciclo pétreo de la historia americana. Pero no es así.

Es hora de conmemorar, entre otros, a Miguel Estatua.

\section{V}

Miguel Estatua era un obrero que, en la ciudad de Nueva Córdoba, un día había descubierto que la montaña estaba llena de animales y que era posible, y que era bueno, sacar estatuas de las rocas. El carácter legendario 
y mítico de este artista popular de raza negra se recalca al emplear el narrador una serie de términos bíblicos (que progresan desde el Antiguo al Nuevo Testamento, desde el Génesis hasta la Crucifixión) para describir su epopeya así como su martirologio final. Cuando los militares que han jurado defender la ciudad, alzada contra el Primer Magistrado, se dejan comprar por el gobierno, repitiendo el mismo fatigante e incansable ciclo de rebeldía y traición que tanto se percibe en América Latina, Miguel decide intervenir, poniéndose a la altura de su nombre (Miguel es el Príncipe del Ejército de Dios contra Satanás, El que Combate en el lugar del Señor), y muriendo como Cristo. Pero esta oposición a la tiranía (que, notemos, es lo que impedirá al dictador ser recibido en los salones parisinos, debido a las fotos que circulan de la masacre) no se reduce a términos exclusivamente políticos. Miguel es el alter ego del Primer Magistrado por su actitud hacia la historia, la cultura, la naturaleza. El dictador siempre justifica su estrategia violenta por el carácter de la tierra en que le toca actuar: el instinto, la ley de la selva, el encono natural, lo mueven a una lucha sin cuartel del más fuerte (por ej., pp. 44-45). Miguel no es poseído por la naturaleza como jungla despiadada, sino que trabaja con su tierra para extraer de ella animales bellos, es decir, realizando no la dimensión demoníaca sino la divina del hombre, su función redentiva. Su rebelión contra el Anti-Cristo (prefigurado ya en la negativa, meses antes, de hacer una estatua suya) es el resultado directo y lógico de su amor por Ámérica, de su capacidad de trabar en ese amor una unidad entre arte y tierra y, finalmente, lucha social. Para la actividad de Miguel Estatua se titiliza el mismo verbo, sacar, que hemos observado en el caso de la momia y de Ataúlfo Galván, pero no para sacar del fango y llevar a la supuesta pulcritud de la cultura, sino para que la potencia terrenal pueda ser labrada de una manera tal que sus productos no se opongan codificados y ajenos a los hombres sino reconciliando al gestador con su trabajo, en una verdadera estética (y utopía) de la producción ${ }^{13}$. Una visión emparentada, en todo caso, con la de Neruda en el Canto General. ${ }^{14}$ Frente a las estatuas que contienen y delatan toda la falsedad pasiva del Primer Magistrado, las de Miguel, más de una década antes, indican otra dirección posible de la historia, la posiblidad-paloma de participar en ella de una manera diferente.

13. Para una discusión pertinente a este punto sobre producción y creación estética, ver la introducción de Stefan Morawski a su edición (con Lee Baxandall) de los escritos de Marx y Engels sobre literatura y arte (Marx-Engels, On literature and art (New York: International General, 1974, especialmente pp. 18-25).

14. Ver mi ensayo, "Correspondencia americana: poeta, pueblo y naturaleza en un poema del Canto General". (Nueva Sociedad, Costa Rica, 1975). 
Esta perspectiva liberadora, alternativa, nunca estará del todo ausente de la novela. Al principio, por cierto, casi no llama la atención del Primer Magistrado. La estrategia narrativa consiste justamente en permitir al lector darse cuenta de la feroz trascendencia de la lucha popular y social contra la dictadura en la misma medida con que va gravitando en la óptica del protagonista. No se trata de reproducir las etapas de esta aparición del pueblo como contrafigura central, pero es indudable de que poco a poco el interés de la novela va desplazándose hacia las fuerzas que lograrán derrocar al tirano. Podemos observar, en general, que el movimiento subversivo y revolucionario avanza en directa relación con la apropiación que hace el Imperio de la economía y de la vida cotidiana del país (para no ir más lejos, la primera Navidad en que aparece Santa Claus es seguida por la primera Semana Santa en que se inventa la Huelga, que es la resurrección de la lucha de Miguel Estatua por otros medios). Esta lucha colectiva se encarna en El Estudiante, quien le da razón y organización, proyectos y metas, a lo que en Miguel Estatua era rebeldía instintiva y espontánea. Más que analizar la dimensión social y política de este personaje, que a ratos nos parece un tanto estereotipado, interesa situarlo como un crítico de la vía que ha concebido el Primer Magistrado hacia la eternidad y la historia. Porque el dictador le propone al joven agitador una beca en París, es decir, que se haga gente a la manera de la momia o de los asistentes a la Opera. La respuesta es aleccionadora: "Yo nada tengo que hacer en París." Tanto Miguel, entonces, como El Estudiante, han escogido un modo de persistir en la historia que nada tiene que ver con el del Primer Magistrado: se niegan a ser sufrientes de la realidad, sea como pasivos dictadores o como pasivos oprimidos. Procuran hacer la historia modificando la inhumanidad existente, tratando de convertir el continente marginal en centro de voluntad y rebeldía. Todo el poder del Primer Magistrado no logra entreabrir las páginas del Pequeño Larousse para que su nombre resuene hacia el futuro. En cambio, sus dos indefensos impugnadores aparecen, desde el principio, rodeados de un hálito de leyenda, mito, magia, palabras, una re-elaboración colectiva y popular de su existencia, proyectados en hazañas que el pueblo conserva en su memoria y reproduce en su aprendizaje ${ }^{15}$. Hace cien años, anota $\mathrm{El}$

15. Es interesante anotar cómo esta elaboración mítica es esencial para la presentación de ambos rebeldes. El Estudiante recién hace su aparición después de que es leyenda, llevando al Primer Magistrado a largas disquisiciones sobre los mitos en América. El ser de "Cristo Negro" de Miguel Estatua está inserto en el texto casi como si lo estuvieran comunicando las generaciones posteriores, que lo alojan en su imaginación en su doble actividad de generador y mártir. Posteriormente, vemos cómo el escultor es transformado por la Negra Elmira (ella lo recuerda en dos ocasiones), dándole el nombre de Pedro Estatua, olvidando lo accesorio y quedándose con lo esencial. Para que intervenga, entonces, lo "real maravilloso" (cuya presencia en los mitos de Mackandal tanto se ha estudiado en El reino de este mundo) es 
Estudiante en una conversación con su doble, Julio Antonio Mella, camino a Bruselas en 1927, que se repite el espectáculo de un dictador que cae y de otro que se levanta. Ese ciclo durará, responde el otro, "hasta que el público se canse de ver lo mismo." (p. 327). A la estatua auto-justificatoria del Primer Magistrado se opone la estatua cálida y hablante de los animales evangelistas en el sexto día de la Creación de Miguel. Al espectáculo con que el actor consumado sojuzga y ofusca a su pueblo se opone el público que algún día deberá subirse al proscenio. Al ciclo reiterativo de la opresión se opone la espiral dura de una acción liberadora que busca emerger 16 . A la fragilidad del tirano de papel de la periferia se opone la resistencia de esa periferia a ser administrada desde afuera. Para unir cronología (el tiempo objetivo y único) y estructura (el tiempo esencial y sistemático) no hay otro camino que romper con la organización institucional y económica vigente.

La eventualidad de este camino se ve comentada y quizás hasta reforzada por uno de los personajes más extraños del libro y acaso de la producción novelística de Carpentier: el Agente Consular.

La historia del representante norteamericano en Puerto Araguato, que recibe, ampara y despide al derrocado presidente, contrasta con la del Primer Magistrado: él tenía una carrera diplomática brillante hasta que, cierto día, precisamente en París, sus superiores se dieron cuenta de que frecuentaba en demasía ciertos lugares donde se bailaba música negra y caribeña. A partir de ese instante, le han asignado los puestos menos relevantes en los países más atrasados. El Agente Consular, cuya apariencia física podría hacerlo pasar por un blanco, reconoce el llamado irresistible de la raza negra, que es uno de sus componentes, y sufre, en

\footnotetext{
imprescindible la participación colectiva y popular. Me permito esta digresión por la tendencia de varios críticos a abstraer lo "real maravilloso" en una hipóstasis meta-histórica, esencia de una América Eterna, equivalente al "realismo mágico". Sin las masas americanas no puede persistir lo "real maravilloso." Véase mi propio ensayo, "El mito como tiempo y palabra en Hombres de maiz de Asturias (En mi Imaginación y violencia en América, Barcelona: Anagrama, 1972).

16. He estudiado estos dos ciclos en la obra de Carpentier anterior a El recurso del método en "El sentido de la historia en la obra de Alejo Carpentier" en el ya citado libro (Imaginación...), sin poner un énfasis tan intenso en ese motor oculto o "hipocentro" de la historia (como lo llama Lev Osporovat en "El hombre y la historia en la obra de Alejo Carpentier (Casa de las Américas, nov.-dic- 1974, año XV, n. 87, p.10) como ahora lo hago. Entiendo esta evolución como consecuencia de una triple modificación: a) aumenta el rol activo y optimista de ese factor histórico en Carpentier (lo que culmina en La consagración de la primavera, la primera obra suya que va de la derrota a la victoria, en vez del camino antagónico; b) cambia la historia misma de América, con el triunfo y consolidación de la revolución cubana y la búsqueda de la liberación nacional en el resto del continente; c) mi propia posición de crítico varía al pasar por la experiencia movilizadora de la Unidad Popular en Chile, permitiéndome descubrir senderos de espiral donde antes sólo dibujé círculos.
} 
consecuencia, la discriminación ${ }^{17}$. Lo que el Primer Magistrado tiene ante sí es un agente del Imperio, que podría haber ejercido en el mundo un poder bastante más elocuente y duradero que el del propio presidente latinoamericano y que, sin embargo, eligió no desertar sus raíces íntimas y sociales. El traslado de éste a París lo puso en contacto con la música y el arte y el ritmo que fluían en sus venas primordiales y debajo de la engañosa piel blanca (de nuevo, lo teatral exterior se contrasta con el río interior y sustancioso de lo que es real). Es un marginado dentro del Imperio al que sirve y no tiene ilusiones sobre los valores en nombre de los cuales se reprime y subyuga lo latino, lo indígena y lo negro. Ha decidido no disimular ni asimilarse, llevando a cabo desde la metrópoli, la travesía antitética a la que planificaba nuestro pícaro tirano, abandonando la herencia europea que es Norteamérica, para asumir la subordinada y oprimida herencia africana. En lo que se asemeja a su tío-abuelo Gottschalk (es una de las libertades que Carpentier se toma con el tiempo), un compositor que echó por la borda el éxito europeo ("público, palacios, coches, lacayos") para correr detrás de mulatas en el Trópico. Teniendo la posibilidad real de integrarse al poderío de los Césares contemporáneos, el Agente Consular se ha quedado solo con su jazz, su sol y una prodigiosa colección de raíces americanas que ha ido recogiendo en jornadas múltiples a lo largo de nuestras playas, raíces que continene en sí el encuentro de la cultura y de la tierra, el entrecruzamiento híbrido y sincrético que el mar y los árboles continentales han ido forjando en formas reconocibles, anticipando la orientación mestiza que han de tomar el hombre y la mujer que habitan esas tierras si quieren ser auténticos.

La ironía es evidente: en el momento en que se aleja de las costas del país que rigió con mano impenitente, el Primer Magistrado se cruza con alguien que fue fiel a su propia identidad y cuyo único patrimonio son pedazos de naturaleza americana. Ya no se trata tan sólo de que su vía es criticada por el intelectual que niega la validez de París como lugar donde se pueda hacer algo, ni por el obrero que, sin haber oído de esa ciudad, produce esculturas fantásticas que se han de igualar con las de Notre Dame (en los ojos de la Negra Mayorala Elmira), sino por un representante de los mismos norteamericanos que lo echan, y que advierte que ningún éxito mundano compensa la miseria en que desembocan la falsía y la deslealtad hacia los fundamentos propios.

Este día, casi onírico, en que debe partir de América para morir en Europa, se inserta dentro del verdadero viaje que, todos estos años, ha

17. Clementine Rabassa llama la atención sobre la importancia del elemento negro en la novela, en su "The Creative Function of Black Characters in Alejo Carpentier's Reasons of State En (Latin American Literary Review, Spring-Summer 1978, Volume VI, number 12, pp. 26-37), analizando el sentido liberador de los personajes de esa raza. 
estado realizando el Primer Magistrado, y que únicamente ahora comienza a comprender: tenemos ganas de llamarlo un viaje a la semilla, porque de hecho se trata - a la manera de tantos que ha narrado Carpentier-de un viaje hacia atrás en el tiempo, pero como detrás de la semilla está la muerte y no la resurrección, digamos más bien se trata de un viaje hacia... sí, nuestra vieja amiga, la momia.

\section{VI}

Hasta el momento en que despierta a su derrocamiento, el Primer Magistrado se ha vestido con el ropaje del poder, se ha rodeado de gestos y fachadas para alimentar su proyecto de ser recibido en Europa como un igual. Cuando abre los ojos, esa tarde, lo primero que recuerda es haber despertado de esta misma manera cuando fue adolescente, "librado de un apéndice lleno de semillas" (p. 267, subrayado nuestro). Queda, entonces, simbólicamente, y por la avenida de la memoria, devuelto al instante inicial en que inauguró el laberinto que ahora llega a su término: la juventud en que él no era nadie y soñaba con ser gente. A partir de este momento en que le quitan todo lo que ha acumulado y con que pensaba defenderse ante la edad y los avatares de la historia, a partir de este momento en que tendrá que vivir en la Europa que siempre anheló, sin poder retornar a su país, tolera nuestro Primer Magistrado un viaje interior hacia sus orígenes, hacia lo único que le va quedando, hacia lo único que no debió nunca abandonar, hacia la tierra que no es teatro ni máscara ni busto.

En efecto, instalado ya en la Ciudad Luz, listo para entregarse por entero a las delicias de la civilización, lo que hace el presidente es algo cabalmente diverso: comienza a columbrar que lo que le importa es lo típicamente americano. Deja su palacio para acomodarse en el cuarto de la servidumbre, cohabitando ahí con su amante negra que es la única que lo ha seguido, guardándole fidelidad. Ya no lee los periódicos europeos sino que vive esperando los de su patria. El ritmo de las horas, de las comidas, de los sabores, recrea, por medios artificiales, trastocando noche y día dentro de las cuatro paredes urbanas, el mundo de allá y no el de acá.

La paradoja no puede ser más sorprendente. Cuando estaba en América, hizo todo lo imposible por moldear el país hasta que se pareciera a París, lo entregó a la economía y a la moda extranjera. Ahora que reside en Europa, añora lo que su propio cuerpo guarda, desde la infancia misma, el edén de lo sensitivo-intuitivo-emocional. Su vida entera ha estado dedicada a renegar de la tierra, como la vida entera de Miguel Estatua y de El Estudiante se orienta en el sentido de convertir ese amor por lo americano en rebeldía social, en una base de poder que garantice su permanencia en la 
historia y no en la mera memoria sensorial. El diccionario Pequeño Larousse (Je sème à tout vent", reza su irónico título) que lo nutre de frases latinas, no lo conserva en sus semillas de palabras. Sólo le queda el incierto diccionario de los sabores y los recuerdos, lo que poseía al comenzar su ascenso hacia los salones, lo que el Agente Consular no denegó, raíces que ha hecho todo lo posible por amputar. Esta tierra, interior y pretérita, la ha llevado adentro durante toda su existencia. Es lo que ha hecho del personaje algo más que un títere, lo que incluso le ha permitido criticar al Ilustre Académico, disentir de su racismo, tener sus propias opiniones, regocijarse de la realidad. Es lo único que permanece después de ser despojado del poder, aunque su poder no nació de esas raíces sino de su mutilación y entrega. En vez de vivir la unidad, el intento de integridad, entre tierra y sociedad, entre raíz y cultura, entre origen e historia, el Primer Magistrado los dividió y opuso durante décadas. Al sufrir el descalabro, está en condiciones de viajar desde la adolescencia hacia la infancia y la cuna mecedora y de ahí al feto que es la momia ("como feto gigantesco y descarnado que hubiese recorrido todos los tránsitos del crecimiento, de la madurez, de la decrepitud y la muerte, cosa apenas cosa", p. 333), encerrado finalmente en el círculo que él mismo se construyó, incapaz de proyectar su amor por la tierra, el cuerpo que efectuó ese amor, en la historia, en los tiempos venideros donde otros hombres y mujeres podrían recoger su existencia y darle sentido. De tanto tratar de quedar inscrito en los libros europeos, ni siquiera tendrá derecho a ser-como Miguel o El Estudiante-leyenda americana, mito maravilloso y movilizador, permanencia en el lenguaje.

Hasta el momento de su derrota, el dictador ha "ascendido" desde la tierra hacia el poder y la civilización europea. Ahora "retrocede" a la tierra, tanto en el sentido de que la lleva adentro como en la forma menos simbólica del cementerio que lo espera. Ahí se consume la última farsa contumaz de su periplo: la Tierra del Sagrado Suelo Patrio que ostenta su tumba es falsa, es tierra del Jardín de Luxemburgo. Hay que contemplar ese caos (en las palabras de Descartes que introducen ese epílogo), ese mundo dado vuelta. El obtiene, finalmente, la tierra (parisina) por la que mintió, violentó y mató. Tiene su tierra hecha gente. Su última falsificación teatral para visitantes que no vendrán a verlo.

Ha ido a juntarse con su momia. El hecho de que el antiguo rey americano se encuentre, después de muerto, enclaustrado en un museo francés, depende de lo que el presente soberano de América, el dueño del poder actual, ha efectuado con el continente. Al despachar a la momia-cultura, civilización, tierra americana, antepasado-hacia Europa, se condena, en el futuro, a la misma suerte: en vez de ser gente, será nada. 
Por eso, el viaje en el tiempo no puede salvar al viejo dictador. Es un itinerario tan regresivo y sin esperanza como ha sido la ley de su (in)existencia: más allá de la semilla que lo vio nacer, más allá del más atrás de su infancia o su punto de parto y partida, no hay sino el vacío burlón de lo circular. No habrá resurrección en la historia o en la tierra para el hombre que no las fecundó ${ }^{18}$.

El Primer Magistrado arriba a su "Ciudad de Dios", a su Meca de la Armonía y la Ratio, entonces, para anclarse en los túneles del recuerdo, para mirar hacia el pluscuamperfecto, intentando restaurar un rinconcito de América en la rue Tilsit, entregado a sabores, carnes, perfumes, canciones, yerbas, gustos y regustos que se han podido mantener intactos pese al desgaste del tiempo. Su tentativa de organizar todas sus experiencias en torno a la reminiscencia vertebra su último año de vida, pero hay un momento en que él escoge conscientemente olvidar sus antiguos designios y vivir volcado hacia los orígenes. La Negra Elmira sale de compras en ese París que le ha dado la espalda a "su" presidente. Este ser, el único que no le falló, se orienta por el sol primitivo en medio de las sombras de la ciudad desconocida, permitiendo, de paso, una mirada iniciática y sagaz de pueblo, una perspectiva diversa, ante "el Santo Lugar del buen gusto, del sentido de la medida, del orden, de la proporción, dictando normas de urbanidad, elegancia y saber vivir, al mundo entero." (p. 25) Y cocinará una comida como las de allá. El banquete arrastra hacia el pretérito no sólo al Primer Magistrado, sino también a su misma hija Ofelia, una snob enferma de arribismo, la lógica prolongación monstruosa de los anhelos escaladores de su padre. Ella desciende también hacia su infancia, hacia su América olvidada, hacia un amor (que ya no siente) por su Polonio progenitor. "Una emoción repentina, venida de adentro, de muy lejos, de un pálpito de entrañas..."(p. 315) le aligera el cuerpo, y pierde, de súbito, treinta años, junto con sus modales, su maquillaje, su barniz civilizado. Ella se ha hundido, con un gozo indescriptible, en la memoria involuntaria de lo que ella genuinamente es, de algo permanente e intemporal.

No es muy difícil anotar que esta escena tiene un parentesco tangible con aquélla, célebre, en que, hacia el comienzo del primer tomo de $A$ la

18. Este viaje hacia atrás no es una novedad en Carpentier. La tesis de Manuel Durán sobre el viaje retroactivo del marqués en el cuento "Viaje a la semilla" permite sospechar el sentido social de ese tránsito o retroceso. El considera que no se trata de un mero juego literario, sino de un juicio moral que hace al héroe "volver a vivir, al revés, una vida que no supo utilizar" y que es "toda una sociedad colonial que con él fracasa y es condenada a la desaparición." (Manuel Durán, "Viaje a la semilla: el cómo y el porqué de una pequeña obra maestra," en Asedios a Carpentier, selección y notas de Klaus Müller-Bergh, Editorial Universitaria, Santiago de Chile, 1972, pp. 63-87. Las citas son de la p. 84). 
recherche du temps perdu, de Proust, el joven Marcel recibe, por medio de una Madeleine que lo transfiere a su infancia, una primera intuición espléndida y confusa acerca de la estructura del tiempo y del mundo que ha de ser confirmada, décadas y volúmenes más tarde (pero escrito por Proust a continuación), cuando un traspié en un patio repite la deslumbradora operación introspectiva, permitiéndole ahora comprender que existe una red secreta de signos y aventuras capaces de restituir el tiempo y las cosas.

Sin que sea necesario realizar una comparación detallada de ambos textos, vale la pena verificar, sin embargo, que el hallazgo del narrador de Proust lo fuerza a posesionarse de la totalidad del transcurso de su historia, la propia y la de la sociedad en que se mueve, mientras que el de nuestro Primer Magistrado no se resuelve en ningún acto creador o recreador, no le hace poner orden en su desorientada y frustrante vida. El expresidente ha dilapidado años negando aquella intemporalidad eterna que entrevé ahora en los resquicios de sus sensaciones y en atmósferas que quisiera infiltrar desde ojos y oídos y dedos. La fuente original de aquellas maravillas que detienen el tiempo no sólo está separada de él por un océano físico, sino por toda su insensata "trascurrencia", por el continente que él ha ayudado a fragmentar, por el caos del subdesarrollo y la dependencia. Para poder recuperar el tiempo perdido, para cohesionar pasado y presente, para conciliar el yo que observa con los demás que actúan y aparentan, para convertir el espacio real en espacio imaginario, el progatonista de Proust tiene que vivir morosamente la historia, tiene que acumular y analizar, una a una, las experiencias que, por último, darán paso a núcleos de integración sintética magníficos. Lo que se descubre, entonces, pese a la crisis que sacude ese mundo, es la continuidad y coherencia de la conciencia. Tal empresa, quizás posible para un intelectual francés que transmuta su vida en el libro de su vida, le está prohibida al dictador americano, cuyos libros todos han sido escritos ya por otros hombres de los países industrializados, que se ha puesto como finalidad ser palabra ya vocalizada en bocas ajenas, un texto establecido y congelado por la metrópoli. El único libro auténtico que pudiera intentar el Primer Magistrado es El recurso del método que contiene, para él, la misma verdad que $A$ la recherche para el protagonista-narrador Marcel.

Pero el constante extravío de la primera persona, precipitándose hacia la tercera, nos indica que, para el dictador, no hay continuidad entre su punto de partida y los acontecimientos que lo siguieron, su conciencia no puede edificar puentes que su acción histórica dinamitó y convirtió en abismos. Lo que recupera el Primer Magistrado en su exilio es lo mismo que tenía su cuerpo hace sesenta años atrás: su intervención en la historia no ha modificado en lo más mínimo ni prolongado ese sustrato emocional y sensorial. Remontar el tiempo, en definitiva, es saltar al estático regreso, 
hacer de cuentas que lo demás-lo que hicimos, lo que nos hicieron-era enteramente ilusorio, quizás un ludens en espera de volver a ser niño en la segunda vejez. Ya en Los pasos perdidos, Carpentier había comprobado que no hay retorno duradero a los orígenes, si no es como un acto reiterado de fertilidad que respira hacia la historia. El Primer Magistrado no encuentra en su retorno al paraíso infantil ninguna clave que reconstituya en un acto de comprensión totalizadora el sentido de lo que ha vivido: aunque él pudiera hallar en esa trayectoria las lecciones de su fracaso como ser humano, no es más que una nueva escala en su evasión de la realidad. En su ocaso es devuelto a su fuente primigenia sin que, entre tanto, haya avanzado en absoluto, traiga algo de su viñedo para depositar en la cosecha. "He abandonado mi casa; perdida es mi herencia" (p. 278), lee el Presidente en la Biblia el día de su derrocamiento. Así, el círculo insignificante que lo ha plagado a lo largo de su carrera termina atrapando hasta a la memoria, negándole la facultad (proustiana) de reinterpretar y superar el pasado, de superar lo "mediocre, contingente, mortal". (Du coté du chez Swann, Gallimard, p. 70). No ha elevado a conciencia dinámica los recuerdos de su re-cuerpo, porque la conciencia no defendió la independencia de ese cuerpo, porque el cuerpo no se unió a otros cuerpos para liberar esa conciencia.

Este breve excurso comparativo nos ha permitido iluminar, desde otro ángulo, las mismas limitaciones del dictador. Su inclusión en estas páginas, sin embargo, no tendría mayor sentido si no fuera porque la presencia de Proust en el El recurso del método, lejos de quedarse circunscrita al préstamo (paródico) de una escena determianda, es esencial para la aprehensión crítica de la novela y su estructura.

\section{VII}

A Marcel Proust no se lo nombra ni una vez, por cierto, en el texto de $E l$ recurso del método. Es una omisión que no puede ser casual. El autor ha debido prepararla cuidadosamente, puesto que llena el horizonte de su dictador con una abundancia casi asfixiante de referencias indirectas al novelista francés, a sus amigos, a sus libros, a sus personajes, a los títulos de sus volúmenes.

Una breve recorrida, que no pretendemos exhaustiva, alcanzará a sancionar el punto.

Ante todo, el mundo social de París al cual aspira a integrarse el Primer Magistrado, está formado por una extraña mezcla de seres humanos reales y ficticios, en los dos casos ligados a Proust. Reynaldo Hahn, el músico 
venezolano, que fue el confidente de Proust y que llevó con él una correspondencia de toda una vida, es el encargado de explicarle al presidente por qué, después de la masacre de Nueva Córdoba, ya nadie lo quiere recibir. Louisa de Mornand, otra amiga con que Proust se carteó, no le quiere contestar el teléfono al personaje de Carpentier ${ }^{19}$. Como si esto fuera poco, el doctor que lo atiende en su lecho de muerte, el Dr. Fournier, lleva - acá puede tratarse de una coincidencia-el nombre de un colega del padre de Proust que asistió al funeral de su madre en $1905^{20}$.

Pero más importante que estos seres históricos, son los imaginarios. Tanto en la mansión del Presidente de la rue Tilsit como en su casa de Marbella, a orillas del Pacífico americano, cuelgan varios cuadros de Elstir, pintor que inventó Proust en su libro. Hasta se nos informa que este artista, después de la guerra, ha intentado ponerse al día en la modernidad, fracasando en forma terminante, es decir, Carpentier le da un desarrollo posterior a un personaje de otro autor. En la música, ocurre otro tanto: se menciona en diversas ocasiones a Vinteuil y su sonata, que fueron creados por Proust - como en el caso del pintor - a partir de varias fuentes reales. Igual suerte para la topografía del Primer Magistrado: en la Francia contemporánea, se habla de Balbec y de una taberna en el Bois (rue des Acacias, ambos lugares inexistentes en la geografía real pero ubicables en la que se ha construído en Du côté de chez Swann). El Primer Magistrado se vanagloria, además, de haber sido invitado tres veces a las veladas de Madame de Verdurin, donde transcurre más de la mitad de las miles de páginas de $A$ la recherche. Y si con ese dato se abre el libro de Carpentier, al final el ex-presidente tiene aún más miedo de llamarla para hacerse invitar, puesto que ahora ella está emparentada con príncipes. Con lo que vemos que El recurso del método no sólo aposenta dentro de sus páginas muchos de estos personajes de Proust, sino que llega incluso a consignar, en su propio transcurso, cambios paralelos que suceden en el mundo de ficción, como el matrimonio que une las dos ramas, las dos vías y caminos que el narrador Marcel ha estado observando y asociando todos estos años. Otros personajes menores tienen una aparición efímera en $E l$ recurso del método: el violinista Morel tampoco responde el teléfono, Brichot rechaza al Primer Magistrado con indignación, se menciona de paso a los Forcheville y otros, asiduos escaladores que rodean a los Verdurin.

19. Philip Kolb ha ido estableciendo la correspondencia, que a partir de 1964, se publica exhaustivamente en Plon, Paris.

20. George Painter, Marcel Proust. A biography, 2 volumes, 1965, (London, Chatt \& Windus, 4th impression, p. 49). El libro de Painter, muy controvertido (especialmente en Francia), es una fuente indispensable para la vida de Proust. Le debemos muchas de las observaciones que hacemos sobre esa vida en este ensayo. 
A esta presencia hay que añadir varias menciones de tipo literario que van desde la escena que hemos analizado y otras ${ }^{21}$ hasta la inserción irónica de los títulos de varios de los volúmenes de $A$ la recherche dentro del texto de El recurso. La primera, cuando el Primer Magistrado se refocila en el castigo que los alemanes habrán de inflingir a los franceses en la guerra: "Y esta orgullosa y pervertida metrópoli conocería una purificación por el fuego que más de un escritor católico de aquí hubiese presentido, comparándola con Sodoma y Gomorra" (p. 115, subrayado nuestro). Y la segunda, cuando se pone a descansar al lado del Pacífico, después de aplastada la rebelión de Hoffmann: "sosiego y reposo hallaba, por fin, el Primer Magistrado, a la sombra de los cañones en flor." (p. 146, subrayado nuestro).

Estas referencias son las más obvias, las más llamativas. Sintomatizan una situación que, de mirarse con detenimiento, revelará una dependencia aún mayor. Porque el mundo parisino del Primer Magistrado es, de hecho, el mundo de Proust, una combinación de su universo social efectivo y de la recreación literaria que efectuara de esa sociedad. Leen los mismos diarios, acuden a los mismos lugares, respiran el mismo aire, contemplan las mismas representaciones de ballet y de ópera, se embeben de los mismos libros. El Primer Magistrado vive de la chismografía y del ocio, de la conversación seudobrillante y del prestigio que ésta otorga. Comparten un contexto, un inter-texto, un pre-texto. Veremos que también se sobreponen en un texto. En efecto, no nos sorprenderá percibir que $E l$ recurso del método se abre un día (la jornada de los Drags) a fines del año 1913, y que en esa misma fecha se publicaba el primer volumen de $A$ la recherche ${ }^{22}$. Quizás tampoco nos admire que la fecha de término del libro de Carpentier, y de agonía de su protagonista, sea la Jornada de los Drags en 1927 , a los catorce años matemáticos, lo que coincide con la aparición del séptimo y último tomo de la obra de Proust. La acción del dictador, por lo tanto, se enfoca en los catorce años que tardó en publicarse la novela francesa: su aparición y desaparición como personaje coincide con la evolución de un libro real, un libro que, además, retrata la sociedad a la que él ha querido pertenecer sobre todas las cosas del mundo. Para que no nos estanquemos en el aspecto literario de este juego, anotemos, como expertos hípicos, que su odisea se extiende, como para el Caballo de

21. Por ejemplo, hay un claro paralelismo entre la visita al mercado de la Mayorala y la que hace Françoise, la criada de $A$ la recherche. Ambas, a través de la cocina, elevan lo cotidiano a arte.

22. Me parece probable que el libro de Carpentier se abra el 13 de noviembre de 1913, el día de la aparición de $D u$ coté de chez Swann. No disponemos en este momento de la documentación que permitiría comprobar esta hipótesis, que sin duda aumentaría la ironía y el pathos de un personaje que lee los diarios sin leer las críticas del libro al que él debe su existencia. 
Calígula, entre dos aperturas del Steeplechase francés en Auteuil (lugar de nacimiento de Proust, dato que nada tiene que ver con nuestra hipótesis): de nuevo su "carrera" aparece asfixiada por una circunferencia que rueda a su punto de partida, dos eventos sociales idénticos en que caballos, carruajes y hombres dan vuelta en redondo.

Comenzamos a entender, ahora, que la fragilidad del Primer Magistrado es aún mayor de lo que creíamos. No sólo no será admitido a los salones del mundo civilizado que añoraba de joven. Es hasta tal punto marginal que ni siquiera puede entrar a los salones de ficción que un escritor francés ha imaginado. Es tan muerto entre los muertos, como diría Baudelaire, un personaje de tan ínfima categoría ontológica, que no logra ser parte, no ya del mundo europeo, sino de la literatura europea misma. Cuando Proust llevó a cabo la atiborrada, extenuante exégesis social de ese mundo en decadencia, no tuvo tiempo para fijarse en él, no logró regalarle siquiera la inmortalidad que entrega a sus sirvientes, cocineros, choferes y lacayos. Sus tres visitas a Madame Verdurin no quedaron flotando en las reminiscencias de un narrador que se propuso como empresa central de su existencia no olvidar nada, absolutamente nada. Nada, salvo al dictadorcito.

La ceguera del Primer Magistrado, que ya se habia advertido a raíz de su incapacidad para medir bien la fuerza e intenciones reales'de los verdaderos luchadores (el imperio y el proletariado naciente), adquiere un nivel casi infinito. Durante sus breves catorce años de existencia (literaria), él tiene ante sí una incitación permanente para conocer la novela francesa de cuya publicación él depende: debió-en esos círculos, frecuentando a Reynaldo Hahn, a Louisa de Mornand, conociendo a Calmette (el editor del Fígaro que pidió la colaboración de Proust), leyendo los diarios en que de vez en cuando publicaba el novelista francés,- haberse topado con él alguna vez. Pero tal ignorancia en un ser tan regresivo y conservador es natural: el mundo snob que Proust somete a una crítica insobornable 23 es aquél cuyos valores y jerarquías el Primer Magistrado universaliza y alaba, sin darse cuenta de las mezquinas fronteras de esa clase social, de su crueldad, de su falta de lealtad y cariño hasta con los suyos. A él se le hace sufrir el peor de los desdenes: al snob, que se desvive por pertenecer, por subir más allá, aparentando un discernimiento y gusto que no tiene, la exclusión es el más dantesco de los castigos. Ese mundo tan noble y excelso actúa con el presidente americano como si fuera un objeto, con falta absoluta de conmiseración: empleando recursos semejantes a los que el

23. Hay una larga polémica acerca de este punto. Coincidimos, en general, con quienes (Levin, Benjamin, Camus) ven a Proust como un crítico de su sociedad, un superador del snobismo vigente. 
propio dictador emplea en sus tierras calientes. Es algo que el narrador Marcel, en $A$ la recherche, descubre una y otra vez, pero que alcanza su momento culminante cuando Swann le anuncia a los Príncipes de Guermantes que él se está muriendo y que le queda un año de vida, y ellos, en vez de quedarse con él esa noche, salen corriendo a una fiesta. Teniendo trempo, eso sí, para que la Princesa se vuelva a cambiar una prenda de vestir que su marido advierte no matiza con el resto de los colores ${ }^{24}$. Esta escena, que inicia la desilusión con ese mundo (que será, en el caso de Proust, afianzado por todo lo que ocurre en torno al caso Dreyfuss y el anti-semitismo vigente) tiene su equivalente y correlato en la última de $E l$ recurso del método cuando Ofelia cierra los ojos de su padre y declara que no se ha de proclamar la muerte para no estropear su jornada hípica ${ }^{25}$. La hija no hace otra cosa que cumplir hasta sus últimas consecuencias el sueño que el dictador había propiciado: en ese círculo social tan culto y supremo no hay sitio para los ancianos, para los débiles, para los moribundos, para losi pobres, para los que no valen. ( $\mathrm{Y}$ por cierto quedan afuera los obreros, los negros, los indios). Al Primer Magistrado, su propia progenie lo tratará como él trató a la momia: como algo muerto, para ser utilizado en beneficio propio, como algo que no debe interferir en los planes actuales.

Como buen rezagado, nuestro presidente ha vuelto a llegar tarde: él quiere meterse en un mundo podrido, que se venía abajo en esos mismos años, cuya decadencia y destrucción Proust presenció y narró, y cuyos eventos principales ocurrieron, incluso, antes del año 1913 en que él despierta en París. Sigue mirando ineludiblemente hacia atrás. Al pícaro americano le falta por completo la conciencia, analítica y sintética ${ }^{26}$ que termina por ser la verdadera protagonista de $A$ la recherche, la necesidad de bucear en una emoción o una experiencia hasta extraerle la esencia. El Primer Magistrado no solamente no logra calibrar las fuerzas sociales que se disputan el siglo XX y que determinan su destino; tampoco es capaz de reconocer las obras de arte de vanguardia que están creando las condiciones para comunicar los terremotos en las emociones y en la comunicación que esa lucha significará.

Esto nos ayuda a entender mejor el uso frecuente de Descartes en el libro. Las citas de este filósofo francés introducen cada capítulo y encabezan algunos. de los subcapítulos, como "contrapunto irónico de

24. He seguido, para la interpretación de este incidente, el magistral punto de vista de Harry Levin en su libro The Dates of Horn: $A$ study of five french realists (New York, Oxford University Press, 1966. Ver especialmente pp. 400-407).

25. Recordemos una situación parecida en Père Goriot, cuando las hijas bailan mientras el viejo agoniza.

26. Para una visión de estos dos procedimientos de Proust, ver de J. Y. Tadié Lectures de Proust (Paris: Armand Colin, 1971, especialmente pp. 164-166). 
nuestro ser social imprevisible, inestable y asimétrico" 27 , como burla de los esfuerzos miméticos grotescos del Primer Magistrado. El título mismo es un juego de palabras sobre $E l$ discurso del método. El Primer Magistrado toma como su modelo un mundo que aparenta ser racional, iluminado, armonioso, medido, que proclama su cartesianismo y la pre-eminencia de la inteligencia y del espíritu. Los métodos y recursos que aplica en su propia comarca para escalar hasta ese mundo ilustran, por cierto, otras urgencias y otra manera de entender el orden (público).

Los días postreros del dictador transcurren, además, en el momento en que se está clausurando, en vísperas de la primera guerra, el orbe mismo de Descartes, en que sus fundamentos sociales y morales han de desintegrarse. Proust basa, justamente, su obra en la destrucción de las normas y apriorismos que para Descartes constituyen las condiciones de funcionamiento de la realidad normal, estableciendo otra relación entre la conciencia, el tiempo y el espacio. El Primer Magistrado, entonces, se precia de cartesiano cuando ya en Europa se explora otra concepción, científica, artística, filosófica, del mundo, cuando los europeos descubren entre otras dimensiones de lo humano, la validez (y la amenaza peligrosa) del instinto, de la emoción, de la memoria involuntaria, de la intuición, rasgos que en América no hay que buscar en oscuros armarios o resentimientos masivos, sino que persiten a la luz de los cuerpos y de los días. A la vez, la razón unilineal idealista cartesiana está siendo sustituída por la razón dialéctica y materialista del marxismo, que en ese mismo período se encarna en su primera revolución triunfante, la bolchevique. El Primer Magistrado vive un verdadero caos, una inversión: aplica al ejercicio del poder la irracionalidad egocéntrica de sus instintos y trata de modelar su cotidianidad en virtud de una razón insigne y civilizada. En vez de imprimir la razón en la política y buscar en su vida privada la concertada aventura de la emoción y del amor que rompería tanto los esquemas oficiales y falsos como el tiempo estacionario y repetido.

Pero tal vez el divorcio entre Proust y el Primer Magistrado se simbolice mejor en la incapacidad de este último de entender la ópera de Debussy, Peleas y Melisanda, cuyo estreno en 1902 había fascinado a Proust. El estreno en el Metropolitan se llevó a cabo recién en 1921, según Carpentier le confidenció a Klaus Müller-Bergh ${ }^{28}$ : una de las libertades que se toma con la historia es trasladar ese hecho a los primeros meses de 1914, precisamente para establecer el carácter retrógado de su presidente, su lejanía del "nouveau monde" que el arte europeo estaba revelando, su lejanía de superficie unilateral que desconoce las profundidades con que se desmiente la realidad positivista de fachada, según ha explicado Adorno ${ }^{29}$.

27. Mejía Duque, art. cit., Recopilación, p. 437.

28. Klaus Müller-Bergh, Talking to Carpentier (Review, Fall '76, Number 18, p. 22).

29. T. W. Adorno, Prisms,(London: Neville Spearman, 1967). 
De todas maneras, la influencia de Proust en el El recurso del método no se restringe tan sólo a su temática, a sus personajes, al mundo social. Parecería que otros aspectos de la novela de Carpentier, como su estructura narrativa o la estrategia de composición, también se relacionan con el cosmos proustiano.

Comencemos por lo más patente. Los siete tomos de $A$ la recherche contagian su número al libro de Carpentier. Hay siete capítulos, más un epílogo (sin numerar). Es un número, como ha señalado Roberto González Echavarría ${ }^{30}$, que se repite constantemente: son 14 los años que dura la acción, son 21 subcapítulos (más el número 22, el ya mencionado epílogo) y todos los trastornos históricos centrales ocurren en los subcapítulos 7,14 y 21. Agreguemos nosotros-a cada cual su obsesión favorita-que son siete las momias en la Caverna y que son 22 pesos el costo del Capital de Karl Marx ("Que lo vendan, que lo vendan; que lo sigan vendiendo," dice el 'Primer Magistrado, cuando le anuncian el precio. "No hay veintidós personas, en todo el país, que paguen veintidós pesos por ese tomo.", p. 189). Podríamos elaborar acerca de estos números, anotando de qué manera el 22, el epílogo fuera del tiempo del dictador, el Capital,las 22 personas que sí lo compraron, rompen la compacta arquitectura que el dictador ha creído instalar en su existencia, resquebrajando el septuor europeo y sintomatizando aquello que no entra en las categorías cómodas, el epílogo que escriben los pueblos de 22 en 22, de Capital en Capital, el subcapítulo que no es momia. Pero no queremos darle una excesiva relevancia a este tipo de repeticiones o juegos. Creemos que el siete indica un hecho bastante importante: la configuración gráfica, casi plástica diríamos, de la biografía del dictador, su duración como texto en esta tierra, la composición musical que lo comenta y textura sin que él lo sepa, todo esto se subordina a la obra de Proust, subrayando la momificación del personaje que ya hemos reiterado hasta el cansancio. Y que el número que cae afuera es la distancia que Carpentier y América han establecido frente a Proust y Europa.

Esta adopción de una obra de arte para organizar el material literario es una operación que le place mucho a Carpentier y que echa a andar en varias de sus obras. La Sinfonía heroica de Beethoven, junto con glosar irónicamente la fuga del anti-Napoleón de $E l$ acoso, sirve para indicarnos los cuarentiséis minutos en que se desarrolla la acción y también el

30. Roberto González Echavarría, "On Reasons of State" (Review ya citado, pp. 25-29). El mismo crítico ha estudiado en El reino de este mundo el sentido que tiene la numerología para profundizar los textos de Carpentier. Resalta en esa novela la "armazón numérica de extremada sutileza y complejidad", el vaivén entre el 12 y el 7 cíclicos, estableciendo que "la magia, la maravilla, será la concordancia entre la disposición numérica de la historia y del texto." (En su ensayo, "Alejo Carpentier", en Narrativa y critica de nuestra América, compilación de Joaquín Roy, Ed. Castalia, 1978, especialmente pp. 146-150). 
transfondo y esqueleto de los leit-motiv del relato. En Concierto barroco, el libro cubre el tiempo entre una ópera de Vivaldi y el momento en los años 30, cuando ese autor es redescubierto, además de experimentar ciertas técnicas musicales barrocas. Más recientemente, en La consagración de la primavera, el novelista busca contrapuntear y unir, siguiendo los movimientos de la pieza subversiva de Stravinsky, la lucha política y la lucha artística del siglo XX, la entrada de los marginados y de la tierra a la música y a la revolución. Y no se trata, en el caso de Carpentier, de una mera fijación en la música (por mucho que sea su arte preferido). Un cuadro inventado, "Explosión en una catedral", concentra y refleja y anticipa los vaivenes paralizados y las reverberaciones de El siglo de las luces. En todos estos casos, la estructura artística ajena se hace propia al servir de marco de referencias para el material literario. Pensamos que $A$ la recherche du temps perdu que, en sí misma, dispone de una recurrente estructura muscial ${ }^{31}$, sirve para darle una armazón firme a la desparramada existencia de un dictador americano, midiendo los esfuerzos del protagonista en función de la red, simultánea en el tiempo, de signos que Proust va diseminando en ese París donde ambos han de morir. Los latidos del dictador durarán lo que dure el libro de Proust. La obsesión de Carpentier, y la de toda su generación, por encontrar un modo de ordenar en función de la cultura un mundo inestable, importado y escurridizo, que el subdesarrollo registra doblemente, se vislumbra acá. Hay entonces, en $E l$ recurso, y en el modo de morar del dictador, un "ordenamiento escondido", la "ordonnance cachée" que André Gide consideró la clave de la obra de Proust 32 .

Es esto, quizás, lo que permite comprender que varias de las leyes mismas de composición de $A$ la recherche se encuentran aplicadas y asumidas en El recurso del método. Ya hemos comentado que tanto el país, como la historia y la figura del dictador, son el resultado de un minucioso proceso de ensamblaje sintético de parte de Carpentier, operando de manera que su libro finaliza por ser la historia de todos los dictadores y todos nuestros países y, además, presentar un mundo único, con la certeza de que se trata de alguien vibrante, verosimil, humano, y no una mera alegoría o metáfora ${ }^{33}$.

31. P. Costil, "La construction musicale de La recherche du temps perdu," (Bulletin des Amis de Marcel Proust, n. 8, 1958 y n. 9, 1959).

32. El juicio de Gide, en la ya citada recopilación de Tadié (pp. 30-35).

33. Vale la pena notar que, si bien en un momento se trata de una metáfora, el verdadero sentido de recuperar el pasado es, en Proust como en Carpentier, un acto de metonimia, es decir, que la experiencia irradia por contigüidad más que evocar analógicamente. Es lo que permite construir el "inmenso edificio" del recuerdo. (Véase el agudo análisis de Gérard Genette, "Metonymie chez Proust ou la naissance du récit", en Les critiques de notre temps et Proust, compilación de Jacques Bersani, Garnier, 1971, pp. 169-180) 
Esta es, ni más ni menos, la técnica del reagrupamiento ${ }^{34}$ que Proust llevó a cabo en la construcción de personajes, escenas y lugares. Así, su inventado novelista Bergotte tiene mucho de Anatole France, pero también extrae varios rasgos de otros intelectuales de la época. El balneario inexistente de Balbec es el resultado de la confluencia de Cabourg, Evian, Trouville. Las figuras ficticias tienen, por lo tanto, componentes reales, pero la suma de todos ellos va más allá del antecedente original: funcionan como seres humanos. En Proust este camino le permite unir lo íntimo con lo histórico, la biografía con la imaginación, la observación con lo que se recrea, lo que se presencia con la elaboración de la memoria: es el modo en que él quiso que su vida permaneciera como obra de arte, lo estético sustentando la experiencia en su momento de aprehensión, en su antes y su después. El mismo, defendiendo su obra en 1914, sugirió que ahí se junta el telescopio con el microscopio, las grandes leyes con los más obstinados detalles, y que la crítica sólo se fijaba en los segundos aspectos y no en los. primeros 35 .

Mario Benedetti ha estudiado de qué manera Carpentier usa el humor en El recurso para obtener el equilibrio exacto entre complicidad y distanciamiento que su tema y modo narrativo requerían ${ }^{36}$. No necesitamos acá repetir sus argumentos, que compartimos. Nos importa ver que junto con esa ironía salvaje y bulliciosa, Carpentier utiliza este otro método, este otro recurso, intentando resolver dilemas estéticos que ni Proust ni sus seguidores se plantearon:

¿Cómo presentar, simultáneamente, la historia como círculo repetido de la opresión, y la historia como espiral liberadora? ¿Cómo mostrar un personaje dominante y abominable desde adentro y a la vez conservar una cierta simpatía y conmiseración hacia él? ¿Cómo insertar al dictador en un mundo rígido, una red de contingencias históricas, y también hacerlo apuntar hacia lo que es su estructura profunda y permanente? ¿Cómo es posible morar en el calendario y en el sistema? ¿Cómo es posible hacer una obra plenamente americana sobre un período, un hombre, un continente forjados desde modelos y presiones exteriores?

34. Para la técnica de "régroupement", ver Jean-Yves Tadié, Proust et le Roman (Paris: Gallimard, 1971, capítulo "Techniques du récit", pp. 366-412).

35. Ver B. G. Rogers, Proust's Narrative Techniques (Genève, Droz, 1965, el primer capítulo).

36. El ensayo de Mario Benedetti, "El recurso del supremo patriarca" apareció originalmente én Casa de las Américas (septiembre-octubre 1976, año XVI, n. 98), así como en la Revista de Crítica Literaria Latinoamericana. Se puede encontrar en su libro, del mismo título, publicado por Nueva Imagen, de México, en 1979. 


\section{EPÍLOGO}

Alejo Carpentier llega a París en el año 1928: es el año después de que morirá su personaje, el año que sigue a la publicación de Le temps retrouvé. La diferencia con su Primer Magistrado no podría ser más vasta: viene huyendo de una dictadura (la de Machado) que lo había encarcelado durante siete (sí, en efecto, siete) meses, y conoce a la perfección la obra de Proust, según ha confesado a César Léante ${ }^{37}$. Más aún, "el descubrimiento de Marcel Proust, cuyas obras empezaban a llegar a La Habana, me causó un verdadero deslumbramiento", dice en una entrevista ${ }^{38}$, marcando para él la eventualidad de rebasar las tradiciones narrativas del realismo que calca y reproduce la superficie de las cosas.

Carpentier, por lo tanto, no será el contemporáneo de Proust ni del Primer Magistrado, pero se domiciliará en el mundo que ellos hicieron, que ellos (de maneras harto diferentes) le dejaron. Décadas más tarde, volverá a París como miembro de la misión diplomática de Cuba revolucionaria. Y cien años después del nacimiento de Marcel Proust, cien años después de la Comuna que sacudió los cimientos del mundo al que quería ingresar el dictador ilustrado, en 1971, comenzará a transmitir y trasponer una crónica fiel y sarcástica de esos catorce años que antecedieron su primera estadía parisina.

El novelista cubano es capaz, entonces, de conocer y recobrar-por medio de la lectura, la investigación, el arte, las memorias, los recuerdos, los documentos, la meditación, la recherche- esos años que él no vivió de cuerpo presente y que podrían estimarse perdidos. Su Primer Magistrado habitó esa ciudad durante ese período, y no acumuló ni poder ni cultura suficientes como para aproximarse a la época en que presumía estar actuando, para tener una relación legítima con el libro de Proust en cuyo índice no figurará.

El recurso del método está indicando, por lo tanto, toda una madurez intelectual de Latinoamérica, analizando-como acto estético- el itinerario opuesto al del dictador. ¿Qué mejor homenaje a Proust que utilizarlo a fondo, que hacerlo pasar por el cristal (y el lodo) de América Latina? ¿Qué manera menos dependiente y subyugada de reconocer una influencia, un aprendizaje, una distancia? Lo que es político, por ende, en esta novela, es menos la tesis de El Estudiante o la lucha de las masas o el dinamitazo de Miguel Estatua o la insurrección que demuestra el ser carnavalesco de las instituciones autoritarias, es menos eso, que la

37. La ya clásica entrevista con César Léante, en "Confesiones sencillas de un escritor barroco" (En la revista Cuba, abril de 1964).

38. Citado en la entrevista de la Recopilación, p. 17. 
equivalencia de ese combate en el acto intelectual, la búsqueda y práctica de la independencia perdida, del tiempo que hemos malgastado en este continente de la miseria y de la maravilla.

Aparte de su genialidad, el novelista cubano puede acceder a esta maestría por dos motivos, ambos históricos: porque escribe desde su patria libre que, en los hechos, rechaza el destino de las momias y se atreve, con todas las imperfecciones a cuestas, a poner en práctica otra alternativa, socialista y liberadora: y porque trabaja a partir de una tradición literaria que, cada vez más segura de su identidad, se va apropiando de las miradas del mundo-incluído el europeo-sin miedo.

Así, Carpentier establece con la novela francesa de Marcel Proust una relación de igual a igual, de hermanos diríamos, señalándole en un susurro que no escucha el dictador muerto y sordo, el dictador que sigue matando y mintiendo en Nuestra América de hoy, que la condición de todo diálogo, y de toda permanencia en la historia que hacemos y sufrimos entre todos, es la propia dignidad. 